\title{
Biostimulatory effect of organic and inorganic nutrients on soil biological indicators in diesel contaminated soil
}

\author{
B. O. Uba ${ }^{1 *}$, E. L. Okoye ${ }^{2}$, C. U. Dokubo ${ }^{3}$, T. Azuanichie ${ }^{1}$ and O. M. Nworah ${ }^{1}$
}

\begin{abstract}
${ }^{1}$ Department of Microbiology, Chukwuemeka Odumegwu Ojukwu University Uli, Anambra State, Nigeria. 2Department of Applied Microbiology and Brewing. Nnamdi Azikiwe University Awka, Anambra State, Nigeria. ${ }^{3}$ Department of Science Laboratory Technology, Delta State Polytechnic Ogwashi - Uku, Delta State, Nigeria.

*Corresponding author. Email: ubabright4real@yahoo.com; Tel: +2348069693773, +2348067562127
\end{abstract}

Copyright @ 2018 Uba et al. This article remains permanently open access under the terms of the Creative Commons Attribution License 4.0, which permits unrestricted use, distribution, and reproduction in any medium, provided the original work is properly cited.

Received 28th November, 2018; Accepted 22nd December, 2018

\begin{abstract}
Conventional soil remediation has been known to be expensive treatment. Thus, various strategies have been opted to investigate cost-effective solution to contaminated sites and an example is bio-stimulation. The study investigated effect of organic and inorganic nutrients on soil biological indicators of diesel - contaminated soil. The parameters investigated include determination of $\mathrm{pH}$, conductivity, nitrate, phosphate, total organic carbon, moisture content, temperature, baseline, soil respiration, dehydrogenase activity, urease activity, soil microbial biomass carbon, protease activity, germination index (GI), total viable count technique (THBC and TCHUB), microscopic and biochemical characteristics in 56th days experimental period. The result revealed that the soil is neutral to slightly alkaline in $\mathrm{pH}$, moderate in conductivity, low in nitrate, phosphate and total organic carbon contents, high in moisture content with moderate (mesophilic) temperature. The result of baseline study also revealed that soil respiration is $99.30 \mathrm{~s}$ days,

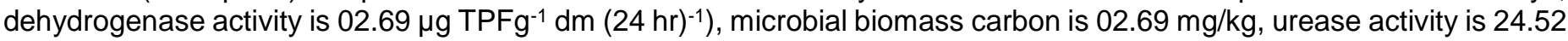
$\mu \mathrm{mol} \mathrm{N}-\mathrm{NH}_{4} / \mathrm{g} 2 \mathrm{hrs}$, protease activity is $36.66 \mu \mathrm{g} / \mathrm{ml}$, Gl is $09.24 \%$, THBC is $06.53 \mathrm{logCFU} / \mathrm{g}$ and TCHUB $06.73 \log C F U$ $\mathrm{g}$. There were significant effect $(\mathrm{P}<0.05)$ on dehydrogenase activities, urease activities, total heterotrophic bacteria counts (THBC) and total culturable hydrocarbon utilizing bacteria counts (TCHUBC) respectively but no significant effect $(P>0.05)$ on soil respiration, soil microbial biomass carbon, protease activity and germination index respectively by the organic and inorganic nutrients. There was negative and positive correlations between germination index, microbial count and other biological indicators measured. More so, the result revealed that the hydrocarbon utilizing bacterial isolates were Aeromonas sp., Serratia fonticola, Citrobacter freundii, Citrobacter diversus and Corynebacterium sp. Thus, application of organic and inorganic nutrients sources is suggested as a good strategy for bioremediation of diesel impacted soil.
\end{abstract}

Keywords: Biological indicators, biostimulation, diesel, nutrient supplements, soil pollution.

\section{INTRODUCTION}

Soil contaminated with petroleum is a serious hazard to human health, causing organic pollution to ground water which limits its use, causes economic loss and environmental problems, decreases agricultural productivity of the soil as well as hinders the microbial nutrient processes and enzyme activities of microorganisms in the soil ecosystem (Emami et al., 2014).

There is mounting evidence that soil microbiological and biochemical parameters may be useful tools for assessing the degree of soil degradation in both natural and agro ecosystems. The measurement of microbiological parameters, such as soil respiration, microbial biomass carbon or enzyme activity, provides information on the presence and activity of viable microorganisms on the intensity, kind and duration of the effects of hydrocarbon pollution on soil metabolic activity (Emami et al., 2014). Also, measured biological indices may provide additional information for bioremediation treatability testing (Topac et 
al., 2009). Reviews have compared a large range of biological indicators for scientific and technical relevance to assist policy-makers in land management (Griffiths et al., 2018).

Bioremediation, the degradation or stabilization of contaminants by microorganisms is claimed as a safe, effective and economic alternative method of environmental clean ups (Salleh et al., 2003). Bacteria have long been considered as one of the predominant hydrocarbon degrading agents found in the environment, they are free living and ubiquitous. Petroleum -degrading microorganisms have enzyme systems and metabolic capabilities, which enable them to withstand adverse environmental conditions. Bacteria abundance, fast growth and wide spectrum of molecules have allowed them to be considered as a bioremediation tool (Rajaei et al., 2013). Biodegradability of hydrocarbons and hence their degree of persistence in natural environment are influenced by various factors, such as the chemical structure of the hydrocarbons which the presence of viable microbial population able to degrade and environmental conditions optimal for microbial degradative activities (Emami et al., 2014). In the presence of abundant hydrocarbon in the environment after a spill, microorganisms cannot effectively attack and utilize the hydrocarbon unless limiting nutrients such as nitrate, phosphate, even micro-elements are incorporated into the polluted medium (van Hamme et al., 2003). Different methods have been employed in order to deliver limiting nutrients and restore petroleum polluted media. Some of these include the use of oil degrading microorganisms, inorganic fertilizers, chicken droppings, cow dung, periwinkle shell, liming and tilling (Leahy and Colwell 1990; ljah and Antai, 2003). Many studies have previously demonstrated that application of nitrogen to soil can improve microbial activity, using a variety of methods including enzyme assays and biomass. Biostimulation using inorganic fertilizer has been employed worldwide in reclaiming oil polluted soil (Orji et al., 2012a, b; Emami et al., 2014). The use of organic nutrients such as chicken droppings, periwinkle shells, pig manure, cow dung for the bioremediation of crude oil polluted environment other than mangrove swamps have been previously reported in Nigeria (ljah and Antai, 2003; Obire et al., 2008). Agarry (2018) reported that the use of nutrient supplements such as inorganic fertilizer, organic fertilizer in terms of animal dungs and agricultural crop residues to biostimulate degraders in polluted matrices has been extensively studied. Extensive research is crucial in order to identify potential organic wastes and inorganic fertilizers in the remediation of hydrocarbon - polluted soil ecosystem.

The utilization of organic and inorganic nutrients to enhance the cleanup of soil contaminated with diesel with respective to soil biological indicators has been investigated by very few studies and this justifies this study. The aim of this study is to investigate the biostimulatory effects of treatment of diesel contaminated soil with organic (cow dung and pig dung) and inorganic nutrients (triton $\mathrm{X}$ and $\mathrm{NH}_{4} \mathrm{Cl}$ ) on soil biological activities. This was used to compare the effectiveness of organic and inorganic nutrient supplements in the bioremediation of diesel polluted soil.

\section{MATERIALS AND METHODS}

\section{Study area}

The diesel polluted soil was obtained from different areas around the generator's premises of Chukwuemeka Odumegwu Ojukwu University, Uli Ihiala Local Government Area, Anambra State, Nigeria. This site was selected due to high level of pollution as a result of oil spillage from the institution generator house.

\section{Sample collection}

The composite soil samples were collected with a sterile spade into plastic buckets which were cleaned with cotton wool soaked in $70 \%$ ethanol to ensure that aseptic conditions were met during sampling (Eziuzor and Okpokwasili, 2009). The soils were collected from four sampling points after excavation, bulked to get a representative sample and then transported to Microbiology Laboratory of the Institution for bioremediation studies. Co-ordinates of the sampling points were determined using Handheld Global Positioning System (GPS) (GPSMAP 76sc). The co-ordinates of the sampling points were $05^{\circ} 46^{\prime \prime} 08.1^{\prime \prime} \mathrm{N}$; $06^{\circ} 50^{\prime \prime} 01.0^{\prime \prime} \mathrm{E}$ (Station 1), $04^{\circ} 47^{\prime \prime} 34.9^{\prime \prime N}$; 006 58 "24.9" E (Station 2), 04²4"34.8" $\mathrm{N}$; 006 $58^{\circ}$ "24.9" E (Station 3) and 04\%47"36.0" N; $006^{\circ} 58^{\prime 2} 24.9^{\prime \prime} \mathrm{E}$ (Station 4). The diesel was obtained from a commercial fuel station, Uli Anambra State, Nigeria.

\section{Physicochemical analysis of soil and nutrients before contamination}

Following the method described by AOAC (2012), the $\mathrm{pH}$ of the soil sample was determined using a bench $\mathrm{pH}$ meter (PHS - 3CU, China); the conductivity and temperature were determined using a conductivity-temperature meter (DSS - 11A, China). The moisture content of the sample was determined by weighing Petri dish and sample before and after drying in the oven (DHG- 9053AA, Life Assurance Scientific, UK) at $105^{\circ} \mathrm{C}$ for $3 \mathrm{hrs}$. The Brucine method reported by United Nations Environmental Programs (UNEP, 2004) was adopted for the measurement of nitrate content at $470 \mathrm{~nm}$ on spectrophotometer (Astell, UV - Vis Grating, 752 W). Colorimetric method was adopted for the determination of phosphate content as described by United Nations Environmental Programme (2004), measured spectro- 
photometrically at $660 \mathrm{~nm}$ and compared with identically prepared standard (water). Total organic carbon (TOC) was measured using the method of Nelson and Sommers (1975) by titrating blank containing oxidant (potassium chromate) and sulphuric acid against the sample and the titre value was recorded.

\section{Soil contamination}

One thousand five hundred (1500) grams of soil sample were placed into each labeled bucket which were four (4) in number and $150 \mathrm{ml}$ of diesel was dispensed into each plastic buckets to stimulate a condition of a major spill (Ezeokoye et al., 2015). The polluted soil was at this point sampled for baseline studies. The hydrocarbon polluted soil was allowed to stand or left undisturbed for seven days before amendment for acclimatization of the biota present (Orji et al., 2012a, b).

\section{Preparation of organic and inorganic nutrients}

Cow dungs, pig dungs, Triton $\mathrm{X}$ and Ammonium chloride, $\left(\mathrm{NH}_{4} \mathrm{Cl}\right)$ were used as the source of limiting nutrients. Cow dungs of about $300 \mathrm{~g}$ were obtained from Odumodu Market, Umunya while pig dungs of about $300 \mathrm{~g}$ were obtained from Okoye Farm located at Nkpor both in Anambra State, Nigeria and were transported to the Microbiology Laboratory of the Chukwuemeka Odumegwu Ojukwu University. Both were air dried for 5 days until moisture driven off completely and was later stored for usage. The inorganic nutrients (Triton $\mathrm{X}$ and Ammonium chloride, $\left.\left(\mathrm{NH}_{4} \mathrm{Cl}\right)\right)$ were purchased from chemical dealers at Head Bridge Market, Onitsha Anambra State, Nigeria.

\section{Nutrient supplementation}

The diesel contaminated soil sample was supplemented with $50 \mathrm{~g}$ of both cow dung, pig dung, $\mathrm{NH}_{4} \mathrm{Cl}$ and $50 \mathrm{ml}$ of triton $X$ according to the method of Ezekoye et al. (2015) as presented in Table 1.

\section{Experimental design}

The laboratory scale experiment was carried out in plastic buckets in triplicate. This was carried out to determine the amount of nutrients that will be used to amend a specific amount of diesel polluted soil. The study was experimentally designed by adopting the method of Eziuzor and Okpokwasili (2009) and Agamuthu et al. (2013). Set up 1 serves as control with only diesel, set up 2 serves as cow dung, set up 3 serves as pig dung, set up 4 serves as $\mathrm{NH}_{4} \mathrm{Cl}$, while set up 5 serve as triton $\mathrm{X}$. All the set ups contained $1500 \mathrm{~g}$ of polluted soil, $150 \mathrm{ml}$ of diesel oil and $20 \mathrm{ml}$ of distilled water. The amendment used in the laboratory based experiment was presented in Table 1.

\section{Bioremediation study}

The experiment was set up in the laboratory for the bioremediation of diesel by withdrawing the amended soil samples for analyses as from day one (immediately after the amendment with organic and inorganic nutrients) till 56th day of the treatment period (Romanus et al. 2015). Then the moisture content was adjusted to $20 \%$ by the addition of distilled water, turned with hand trowel every day for aeration and watered weekly with $20 \mathrm{ml}$ of distilled water throughout the study period. Samples were collected at 2 weeks interval for metabolic and microbial analyses (Emami et al., 2014; Orji et al., 2012a, b).

\section{Soil metabolic analyses}

\section{Determination of soil respiration (SR)}

The metabolic activity of indigenous microorganism was determined as $\mathrm{CO}_{2}$ evolution. Carbondioxide $\left(\mathrm{CO}_{2}\right)$ was determined by adopting the method of Hegazy et al. (2014) using 2 grams of soil sample from different treatments that were transferred into a well labeled plastic vials. The plastic vials were placed in closed 1 litre glass jars. A glass vial containing $10 \mathrm{ml} 0.2 \mathrm{~N} \mathrm{NaOH}$ was placed in each jar to trap $\mathrm{CO}_{2}$ resulting from substrate mineralization. The $\mathrm{NaOH}$ trap was periodically replaced. Ten millilitres of 0.5 $\mathrm{N} \mathrm{BaCl}{ }_{2}$ was added to the $\mathrm{NaOH}$ trap and the amount of $\mathrm{CO}_{2}$ produced by each treatment was determined by titrating with $0.1 \mathrm{~N} \mathrm{HCl}$ and the values were expressed as $\mathrm{mg} \mathrm{CO} 2 \mathrm{~g}^{-1}$.

\section{Determination of soil dehydrogenase activity (DHA)}

Dehydrogenase activity was determined by monitoring the rate of reduction of 2, 3, 5 - triphenyltetrazolium chloride (TTC) to triphenyl formazan (TPF) (Pepper et al., 1995). One $\mathrm{ml}$ of $3 \%$ TTC solution was pipetted into a clean labeled test tube each and $1 \mathrm{ml}$ of the filtrate, $30 \mathrm{mg}$ of glucose, $3 \mathrm{ml}$ of distilled water were added. The mixture was incubated for $24 \mathrm{hrs}$ and read spectrophotometrically at a wavelength of $485 \mathrm{~nm}$ and results were expressed as g TPF $g^{-1}$ dry sample.

\section{Determination of soil urease activity (UA)}

The soil urease activity was determined by adopting the method of Mckee et al. (1988). Moist soil samples of 1.5 grams from different labeled plastic buckets were poured into the labeled test tubes and incubated with $0.5 \mathrm{ml}$ of 
Table 1. Experimental design of the study.

\begin{tabular}{ll}
\hline Experimental setup & Test experiment \\
\hline Setup 1 (control) & $1500 \mathrm{~g}$ of polluted soil $+150 \mathrm{ml}$ of diesel oil $+20 \mathrm{ml}$ of water \\
Setup 2 (Cow dung) & $1500 \mathrm{~g}$ of polluted soil $+150 \mathrm{ml}$ of diesel oil $+50 \mathrm{~g}$ of cow dung $+20 \mathrm{ml}$ of water \\
Setup 3 (Pig dung) & $1500 \mathrm{~g}$ of polluted soil $+150 \mathrm{ml}$ of diesel oil $+50 \mathrm{~g}$ of poultry dropping $+20 \mathrm{ml}$ of water \\
Setup 4 $\left(\mathrm{NH}_{4} \mathrm{Cl}\right)$ & $1500 \mathrm{~g}$ of polluted soil $+150 \mathrm{ml}$ of diesel oil $+50 \mathrm{~g}$ ammonium chloride $+20 \mathrm{ml}$ of water \\
Setup 5 (Triton $\mathrm{X})$ & $1500 \mathrm{~g}$ of polluted soil $+150 \mathrm{ml}$ of diesel oil $+50 \mathrm{ml}$ triton $\mathrm{X}+20 \mathrm{ml}$ of water \\
\hline
\end{tabular}

$79.9 \mathrm{mM}$ urea (substrate) solution for $2 \mathrm{hrs}$ at $37^{\circ} \mathrm{C}$. The release of $\mathrm{NH}^{+}-\mathrm{N}$ from the urea by the soil urease was determined spectrophotometrically at $660 \mathrm{~nm}$ after treatment of incubated soil sample with $\mathrm{KCl}$ and $\mathrm{HCl}$. The activity of soil urease was expressed as $\mu \mathrm{g} \mathrm{NH}_{4}{ }^{+}-\mathrm{N}$ dry wt of soil.

\section{Determination of microbial biomass carbon (MBC)}

Microbial biomass carbon (Cmic) was determined using fumigation extraction procedure (Vance et al., 1987). Ten gram of soil samples was sterilized in $250 \mathrm{ml}$ flask of each set up that were later fumigated with ethanol free chloroform for $24 \mathrm{hrs}$. Then, both fumigated soil and unfumigated soil samples were extracted for 45 mins by $50 \mathrm{ml}$ of $0.5 \mathrm{M} \mathrm{K}_{2} \mathrm{SO}_{4}$ and filtered using Whatman no. 1 filter paper organic carbon in the extracts was measured as above. Soil microbial biomass carbon was estimated from the relationship:

Biomass carbon $=E_{C} / K_{E C}$

Where $\mathrm{E}_{\mathrm{c}}$ is (organic carbon extracted from fumigated soil) minus (organic carbon extracted from non-fumigated soil) and $\mathrm{K}_{\mathrm{EC}}=0.45$ (microbial extraction efficiency) (Wu et al., 1990).

\section{Determination of protease activity (PA)}

Protease activity was assayed by the modified method of Akhtar et al. (2013) using $1 \%$ casein as a substrate. Casein solution $(1.0 \mathrm{ml})$ with an equal volume of suitably diluted enzyme solution from each treatment was incubated at $37^{\circ} \mathrm{C}$ for 10 mins. These were followed by addition of $2 \mathrm{ml}$ of $20 \%$ Trichloroacetic acid (TCA) incubated at $37^{\circ} \mathrm{C}$ for 20 mins. The mixtures were filtered and to the $1 \mathrm{ml}$ of filtrate was added $2 \mathrm{ml}$ of $20 \% \mathrm{Na}_{2} \mathrm{CO}_{3}$ and $1 \mathrm{ml}$ of one fold diluted Folin-Ciocalteau phenol reagent which was further incubated for 30 mins. The absorbance was measured against an appropriate blank at $595 \mathrm{~nm}$. One unit of protease activity was defined as the amount of the enzyme able to produce $1 \mathrm{~g}$ tyrosine $\mathrm{g}^{-1} \mathrm{~min}^{-}$ ${ }^{1}$ and expressed as $\mu \mathrm{g} / \mathrm{ml}$ of enzyme.

\section{Phytotoxicity assay}

Germination experiments were carried out in Petri dishes using soil samples taken 1, 14, 28, 42 and 56 days from the treated soil. Thirty grams of the corresponding soil samples were introduced into plates and moistened with $10 \mathrm{ml}$ of distilled water. Whatman no. 1 filter paper was placed into each of the Petri dishes containing the moist soil while distilled water on filter paper was used as control in other dishes. Ten grams of mustard seed (Brassicca nigra) was first surface sterilized by immersion in $75 \%$ ethanol for 3 mins with periodical agitation and finally washed thoroughly with distilled water. Ten mustard seeds (Brassicca nigra) were placed on each Petri dish. The samples were incubated for 5 days in the dark at $25 \pm 2^{\circ} \mathrm{C}$. After incubation, the number of germinated seeds and the length of each roots were used to determine the germination index defined as:

$\mathrm{GI}=100 \times(\mathrm{Gs} / \mathrm{Gc}) \times(\mathrm{Ls} / \mathrm{Lc})$

Where Gs and Gc are germinated seeds in sample and control, and Ls and Lc are mean root length in the sample and control respectively (Emami et al., 2014).

\section{Microbiological analysis}

\section{Enumeration of total heterotrophic bacteria count (THBC)}

Spread plate method on nutrient agar was used in the enumeration of THBC at 14 day interval. A 10 - fold serial dilution of the treated and control soil samples was carried out by weighing $1 \mathrm{~g}$ each of soil samples into sterile test tubes containing $9 \mathrm{ml}$ of sterile physiological saline and diluted to $10^{-5}$. From each dilution, $0.1 \mathrm{ml}$ was pipetted and inoculated on nutrient agar plate. However, a triplicate plating of each dilution was employed. A sterile glass rod was used to spread the inocula over the media. The plates were incubated for 18 to $24 \mathrm{hrs}$ at a temperature of $37^{\circ} \mathrm{C}$. After which the emerging colonies were counted. Colonies that formed during this incubation period were counted using this formula:

$\mathrm{CFU} / \mathrm{g}=\frac{\text { No. of colonies X Dilution factor }}{\text { Amount used }}$

Values were expressed as colony forming units per g (CFU $/ \mathrm{g})$. The THBC was carried out using Chikere et al. (2009b) procedures. 


\section{Enumeration of total culturable hydrocarbon utilizing bacteria (TCHUB)}

The vapour phase method was used to determine the TCHUB on mineral salt agar containing $0.04 \mathrm{~g} \mathrm{MgSO}_{4}$. $7 \mathrm{H}_{2} \mathrm{O}, 0.03 \mathrm{~g} \mathrm{KCl}, 0.09 \mathrm{~g} \mathrm{KH}_{2} \mathrm{PO}_{4}, 0.04 \mathrm{~g} \mathrm{NaNO}_{3}, 0.13 \mathrm{~g}$ $\mathrm{K}_{2} \mathrm{HPO}_{4}, 2.0 \mathrm{~g} \mathrm{NaCl}, 15 \mathrm{~g}$ of Agar powder, $100 \mathrm{ml}$ of distilled water amended with $0.1 \mathrm{~g}$ of nystatin to inhibit the growth of fungi (Chikere et al., 2009a). Then, it was sterilized by autoclaving at $121^{\circ} \mathrm{C}$ and 15 psi for 15 mins and allowed to cool to about $45^{\circ} \mathrm{C}$. The already prepared medium was poured into Petri dishes and allowed to gel then $0.1 \mathrm{ml}$ of the inocula was spread on plates with rod aseptically. Filter paper (Whatman No 1) was saturated with diesel and the diesel impregnated papers were aseptically placed onto the covers. The diesel saturated filter papers supply diesel by vapour - phase transfer to the inocula. The plates were incubated by inversion for 7 to 10 days at $28^{\circ} \mathrm{C}$. Plates yielding 30 to 300 colonies were enumerated from triplicates and mean values were recorded and calculated in CFU g ${ }^{-1}$ using the formula in the enumeration THBC above. Colonies of different hydrocarbon utilizing bacteria were randomly picked and pure isolates were obtained by repeated sub-culturing on nutrient agar (Hitech, India) (Omoni et al., 2015).

\section{Characterization of the hydrocarbon utilizing bacterial isolates}

Gram staining: This technique divides bacteria into Gram positive and negative. All the isolates were Gram stained by adopting the method described by Cheesbrough (2006).

Biochemical test: This was carried out following Analytical Profile Index (API) kit manual described in Cheesbrough (2006).

\section{Identification of the hydrocarbon bacterial isolates}

The hydrocarbon bacterial isolates were finally identified using Bergey's Manual for Determinative Bacteriology (Holt et al., 1994).

\section{Statistical analysis}

The data were analyzed using Graph-Pad Prism statistical software, version 7.00 (GraphPad software Inc. San Diego, California). Obtained values were expressed as mean \pm standard deviation (SD). Two-way analyses of variance (ANOVA) followed by post Tukey's multiple comparison test were performed on the obtained data. The results were considered statistically significant at $95 \%$ confidence intervals $(p<0.05)$ (Ezeokoye et al., 2015; Omoni et al., 2015; Orji et al., 2012a, b).

\section{RESULTS AND DISCUSSION}

\section{Physicochemical Properties}

The result in Table 2 showed that the $\mathrm{pH}$, conductivity, nitrate, phosphate, total organic carbon, moisture content, and temperature were: $7.40 \pm 0.20,500 \pm 25.00 \mu \mathrm{S} / \mathrm{cm}$, $2.00 \pm 0.40 \mathrm{mg} / \mathrm{kg}, 1.80 \pm 0.20 \mathrm{mg} / \mathrm{kg}, 4.95 \pm 0.10 \%$, and $20.10 \pm 3.00 \%$ and $27.10 \pm 2.45^{\circ} \mathrm{C}$ respectively. The result revealed that the soil is neutral to slightly alkaline in $\mathrm{pH}$, moderate in conductivity, low in nitrate, phosphate and total organic carbon contents, high in moisture content with moderate (mesophilic) temperature.

The result in Table 3 showed that the $\mathrm{pH}$, conductivity, temperature, nitrate, phosphate, total organic carbon and moisture content for cow and pig dungs were $07.50 \pm 0.70$, $340.00 \pm 20.00 \mu \mathrm{S} / \mathrm{cm}, 28.20 \pm 2.00^{\circ} \mathrm{C}, 04.00 \pm 0.50 \mathrm{mg}$ $/ \mathrm{kg}, 02.20 \pm 0.06 \mathrm{mg} / \mathrm{kg}, 06.95 \pm 1.00 \%$ and $40.10 \pm$ $2.50 \%$ and $08.90 \pm 0.55,1,290 \pm 47.50 \mu \mathrm{S} / \mathrm{cm}, 30.50 \pm$ $2.00^{\circ} \mathrm{C}, 04.00 \pm 0.70 \mathrm{mg} / \mathrm{kg}, 02.80 \pm 0.04 \mathrm{mg} / \mathrm{kg}, 03.83$ $\pm 0.80 \%$ and $20.20 \pm 1.30 \%$ respectively. The result revealed that both nutrients were neutral to alkaline in $\mathrm{pH}$, moderate to high in conductivity, low in nitrate, phosphate and total organic carbon contents, high in moisture content with moderate (mesophilic) temperature.

\section{Baseline determination}

The result in Table 4 showed that the soil respiration is $99.30 \pm 10.30 \mathrm{mgCO}_{2} / \mathrm{g}$ days, dehydrogenase activity is $\left.02.69 \pm 0.04 \mu \mathrm{g} \mathrm{TPFg}^{-1} \mathrm{dm}(24 \mathrm{hr})^{-1}\right)$, microbial biomass carbon is $02.69 \pm 0.08 \mathrm{mg} / \mathrm{kg}$, urease activity is $24.52 \pm$ $3.30 \mu \mathrm{mol} \mathrm{N}-\mathrm{NH}_{4} / \mathrm{g} 2 \mathrm{hrs}$, protease activity is $36.66 \pm 6.20$ $\mu \mathrm{g} / \mathrm{ml}$, Gl is $09.24 \pm 1.50 \%$, THBC is $06.53 \pm 0.50 \log$ CFU $/ \mathrm{g}$ and TCHUB $06.73 \pm 0.35 \mathrm{log} C F U / \mathrm{g}$. The baseline data results showed that the hydrocarbon utilizing microbes in the soil is relatively adequate for bioremediation (Ebuehi et al., 2005). This could be because the soil has history of diesel spillage from the big lister generator within the Institution.

\section{Metabolic activities determination}

The metabolic activity of indigenous microorganisms was determined as $\mathrm{CO}_{2}$ evolution (basal respiration). The basal respiration reflects activity of sediment microorganisms, which may be related to the biodegradation of organic compounds. Respiration measurements give an idea of the microbial activity in sediments and the quantity and quality of substrates related to mineralization (Hegazy et al., 2014). The result in Figure 1 showed that the day 28 has the highest value of $149.00 \pm 10.56 \mathrm{mgCO}_{2} / \mathrm{g}$ days on control set up and day 42 has the lowest value of 10.10 $\pm 0.50 \mathrm{mgCO}_{2} / \mathrm{g}$ days on pig dung and triton $X$ set ups respectively. The observed inhibition is probably due to decrease in the microbial population size involved in the 
Table 2. Physicochemical properties soil sample before contamination.

\begin{tabular}{lc}
\hline Parameter & Value $( \pm$ S.D. $)$ \\
\hline $\mathrm{pH}$ & $07.40 \pm 0.20$ \\
Conductivity $(\mu \mathrm{S} / \mathrm{cm})$ & $500.00 \pm 25.00$ \\
Nitrate $\left(\mathrm{NO}_{3}\right)(\mathrm{mg} / \mathrm{Kg})$ & $02.00 \pm 0.40$ \\
Phosphate $\left(\mathrm{PO}_{4}\right)(\mathrm{mg} / \mathrm{Kg})$ & $01.80 \pm 0.20$ \\
Total Organic Carbon $(\% \mathrm{TOC})$ & $04.95 \pm 0.10$ \\
Moisture content $(\%)$ & $20.10 \pm 3.00$ \\
Temperature $\left({ }^{\circ} \mathrm{C}\right)$ & $27.10 \pm 2.45$ \\
\hline
\end{tabular}

Table 3. Physico-chemical composition of cow dung and pig dung before bioremediation study.

\begin{tabular}{lcc}
\hline Parameter & Cow dung $( \pm$ S.D) & Pig dung ( \pm S.D.) \\
\hline $\mathrm{pH}$ & $07.50 \pm 0.70$ & $08.90 \pm 0.55$ \\
Conductivity $(\mu \mathrm{S} / \mathrm{cm})$ & $340.00 \pm 20.00$ & $1,290.00 \pm 47.50$ \\
Temperature $\left({ }^{\circ} \mathrm{C}\right)$ & $28.20 \pm 2.00$ & $30.50 \pm 2.00$ \\
Nitrate $(\mathrm{NO} 3)(\mathrm{mg} / \mathrm{kg})$ & $04.00 \pm 0.50$ & $04.00 \pm 0.70$ \\
Phosphate $(\mathrm{PO} 4)(\mathrm{mg} / \mathrm{kg})$ & $02.20 \pm 0.06$ & $02.80 \pm 0.04$ \\
Total organic carbon $(\% \mathrm{TOC})$ & $06.95 \pm 1.00$ & $03.83 \pm 0.80$ \\
Moisture content & $40.10 \pm 2.50$ & $20.20 \pm 1.30$ \\
\hline
\end{tabular}

Table 4. Baseline study of the soil biochemical, enzymatic and microbiological properties of diesel impacted garden soil.

\begin{tabular}{|c|c|}
\hline Parameter & Values ( \pm S.D.) \\
\hline Soil respiration $\left(\mathrm{mgCO}_{2} / \mathrm{g}\right.$ days $)$ & $99.30 \pm 10.30$ \\
\hline Dehydrogenase activity $\left(\mu \mathrm{g} \mathrm{TPFg}^{-1} \mathrm{dm}(24 \mathrm{~h})^{-1}\right)$ & $02.69 \pm 0.04$ \\
\hline Microbial biomass carbon (mg /kg) & $02.69 \pm 0.08$ \\
\hline Urease activity $\left(\mu \mathrm{mol} \mathrm{N}-\mathrm{NH}_{4} / \mathrm{g} 2 \mathrm{~h}\right)$ & $24.52 \pm 3.30$ \\
\hline Protease activity $(\mu \mathrm{g} / \mathrm{g})$ & $36.66 \pm 6.20$ \\
\hline GI (\%) & $09.24 \pm 1.50$ \\
\hline THBC (LogCfu/g) & $06.53 \pm 0.50$ \\
\hline TCHUB (LogCfu/g) & $06.73 \pm 0.35$ \\
\hline
\end{tabular}

nitrogen cycle, which would affect the degradation of organic compounds. The addition of organic (cow dung and pig dung) and inorganic (triton $\mathrm{X}$ and $\mathrm{NH}_{4} \mathrm{Cl}$ ) amendments to the contaminated soil increased SR (Figure 1). Nitrogen fertilizer is a more easily utilized source of nitrogen for microbial growth when applied to the soil (Marin, 2004). The nitrogen contents of cow and pig dungs have thus been effective. Statistically, there were no significant differences $(P>0.05)$ detected among the stimulatory effect of the organic and inorganic nutrients indicating that all the amended set ups had same effect on soil respiration.

The result in Figure 2 showed that the day 28 had the highest value of $3.93 \pm 0.30 \mu \mathrm{g} \mathrm{TPFg}^{-1} \mathrm{dm}$ on pig dung set up while day 1 had the lowest value of $1.00 \pm 0.02 \mu \mathrm{g}$ $\mathrm{TPFg}^{-1} \mathrm{dm}$ on the control set up. However, dehydrogenase activity was significantly $(P<0.05)$ inhibited in control set up with great significance $(P=0.05)$ in the amended set ups, indicating the toxicity of diesel contamination to microbial activities. Reduction in these enzymes agreed with the work carried out by Akubugwo et al. (2009). Low dehydrogenases in the soil polluted by petroleum spillage were also observed by Malachowska et al. (1997) and Labud et al. (2007). Dehydrogenase enzymes are almost exclusively intracellular and they are involved in organic matter oxidation. They reflect physiologically active microorganisms and thus provide correlative information on biological activities and microbial populations in soils. It described the concentration of petroleum hydrocarbon that had significant effect on activity of soil dehydrogenase (Ueno et al., 2007).

The result in Figure 3 showed increase in all the days of treatment from day 1 to day 56 with day 1 having the lowest value of $7.50 \pm 0.10 \mu \mathrm{mol} \mathrm{N}-\mathrm{NH}_{4} / \mathrm{g} 2 \mathrm{hrs}$ on positive 


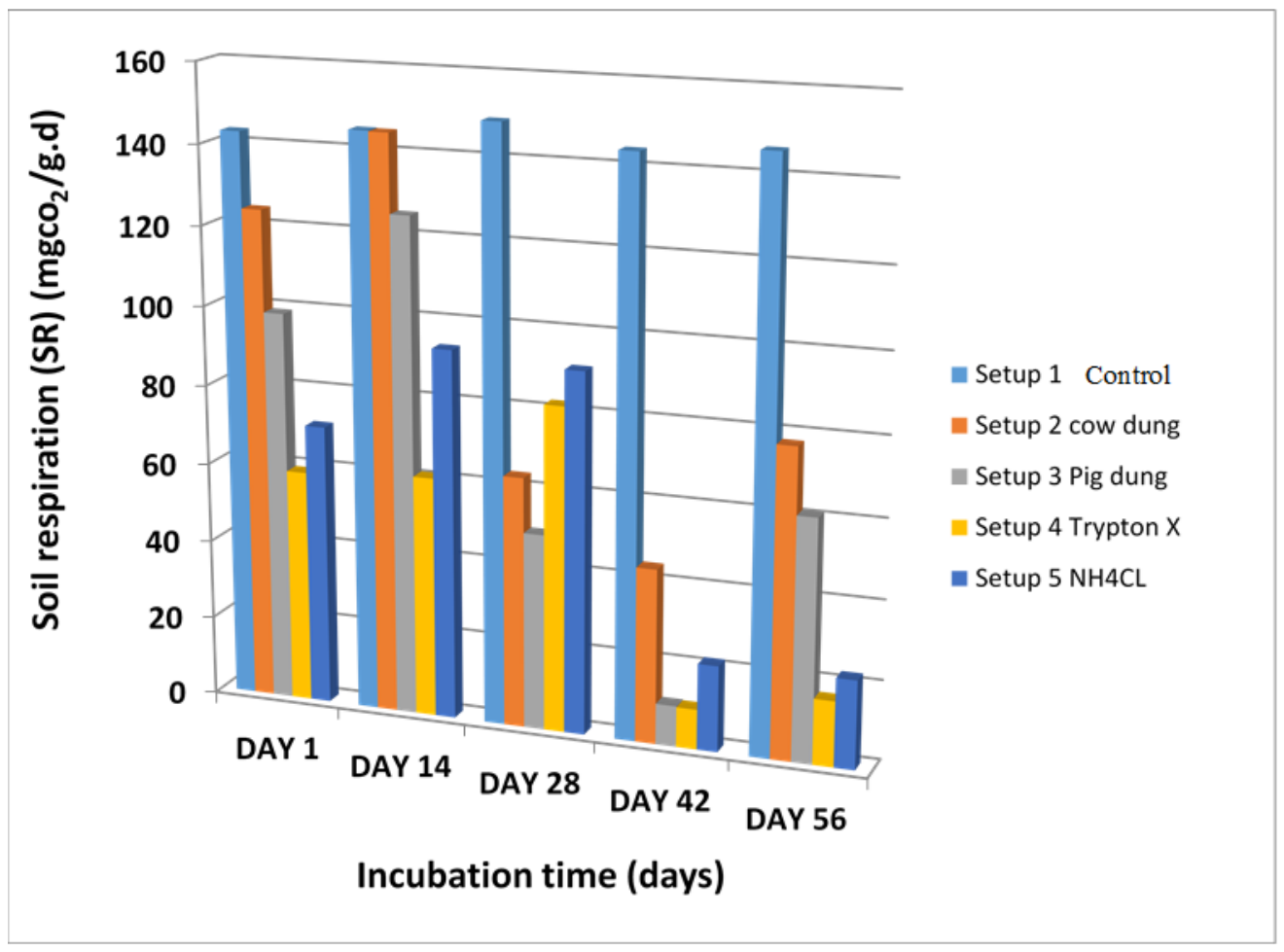

Figure 1. Dynamic changes of soil respiration (SR) in diesel contaminated soils in the presence and absence of cow dung, pig dung, triton $\mathrm{X}$ and $\mathrm{NH}_{4} \mathrm{Cl}$ nutrients during incubation for 56 days.

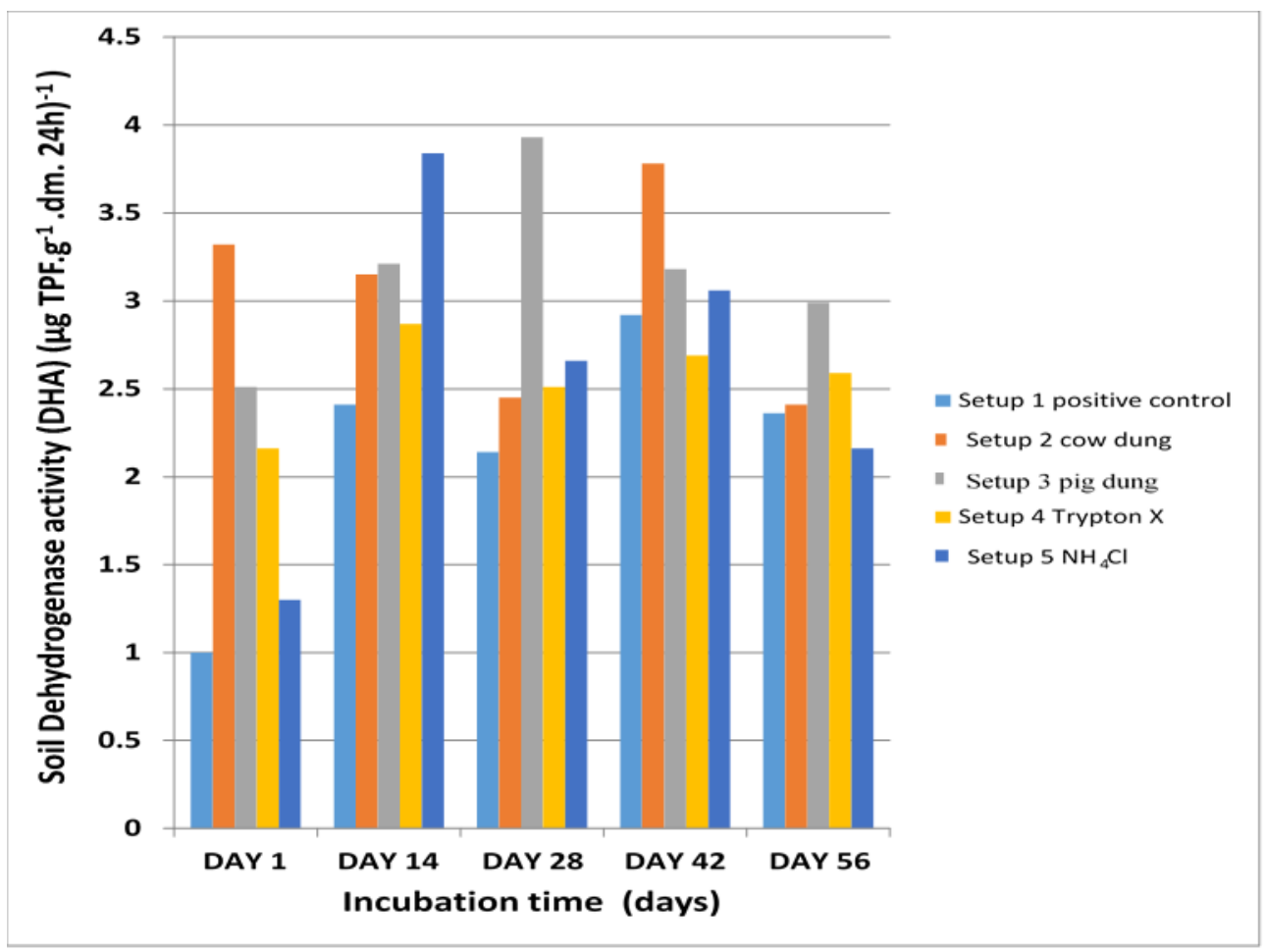

Figure 2. Dynamic changes of soil dehydrogenase activity (DHA) in diesel contaminated soils in the presence and absence of cow dung, pig dung, triton $\mathrm{X}$ and $\mathrm{NH}_{4} \mathrm{Cl}$ nutrients during incubation for 56 days. 


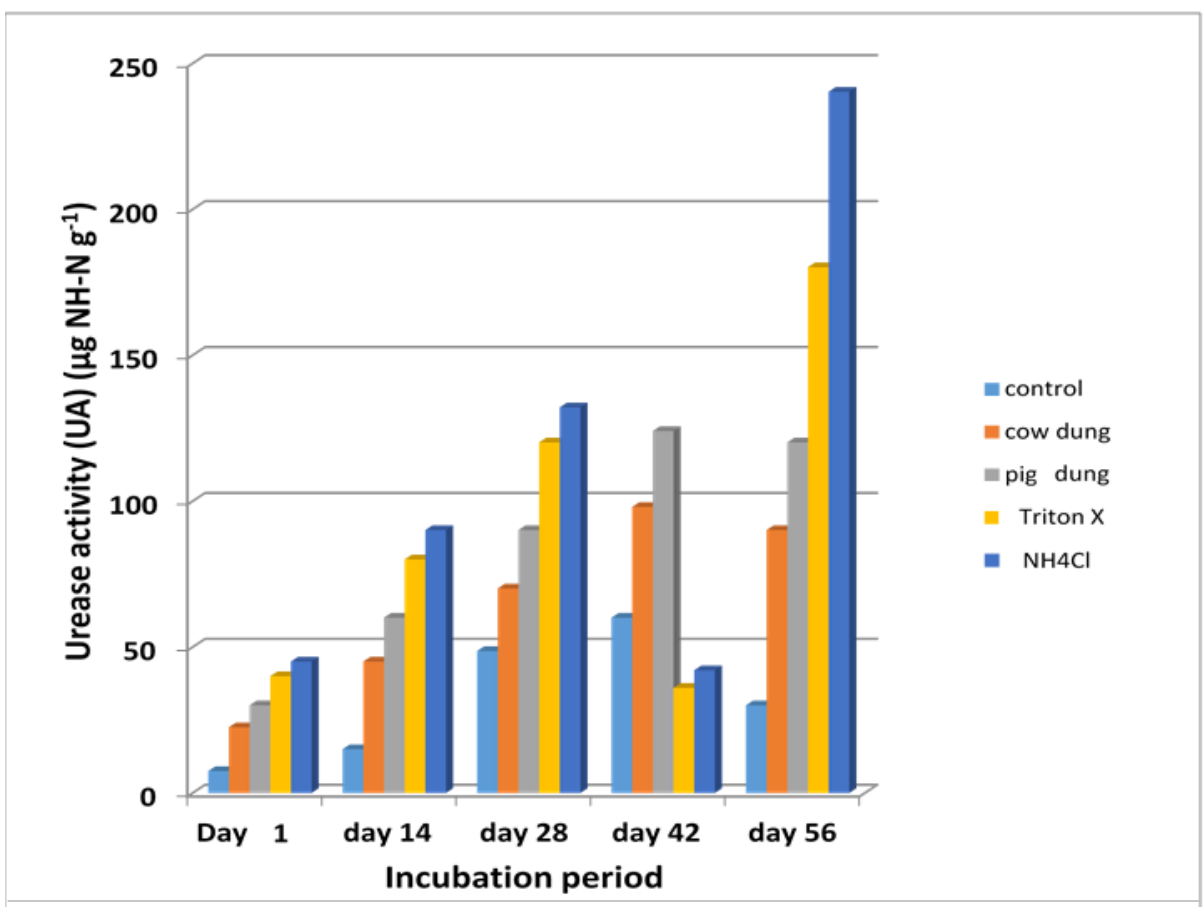

Figure 3. Dynamic changes of urease activity (UR) in diesel contaminated soils in the presence and absence of cow dung, pig dung, triton $\mathrm{X}$ and $\mathrm{NH}_{4} \mathrm{Cl}$ nutrients during incubation for 56 days.

control set up and day 56 having the highest value of $240.28 \pm 15.40 \mu \mathrm{mol} \mathrm{N}-\mathrm{NH}_{4} / \mathrm{g} 2$ hrs on triton $\mathrm{X}$ set up. There was significant increase $(P<0.05)$ in the soil urease activity from day 1 to day 56 (7.50 \pm 0.80 to $30.0 \pm 2.00$ $\mu \mathrm{mol} \mathrm{N}-\mathrm{NH}_{4} / \mathrm{g} 2 \mathrm{hrs}$ ) in all the treatments set up indicating that the wastes had stimulatory effects on soil urease activity. Investigation of soil urease has attracted considerable attention due to the role of urea as a fertilizer to improve soil productivity (Gianfreda et al., 1994; Makoi and Ndakidemi, 2008). Urease activity is frequently used as an indicator for determining the influence of various anthropogenic pollutants on the biological quality of the soil (Margesin et al., 2000; Singh and Kumar, 2008). Like many other soil enzymes, urease can be either intracellular or extracellular. This enzyme, mostly the cases is an extracellular enzyme representing up to $63 \%$ of the total urease activity in soil (Klose and Tabatabai, 1999; Corstanje et al., 2007). Extracellular urease can be either free or immobilized on mineral or organic soil components (Nannipieri et al., 1996).

The result in Figure 4 showed that the day 28 had the highest value of $119.5 \pm 0.80 \mathrm{mg} / \mathrm{kg}$ while day 56 had lowest value of $15.50 \pm 1.60 \mathrm{mg} / \mathrm{kg}$ on pig dung. There was no significant increase $(P<0.05)$ in soil microbial biomass carbon with days in all treatment set ups though with irregular decrease and increase observed in the control of all the days starting from day 1 to day 56 from $25.0 \pm 2.40$ to $21.0 \pm 1.00$ and $24.0 \pm 2.40$ to $26.0 \pm 2.00$ and then to $25.0 \pm 2.00 \mathrm{mg} / \mathrm{kg}$ respectively. Microbial biomass carbon in soil sample is an indicator for biodegradation. Organic matter is decomposed and organic pollutants are removed from the soil by mechanism of microbial biomass (Marschner and Kabitz, 2003). Soil microbial biomass is the main driving force frequently used in agricultural early indicator of changes in soil properties. It can serve also as an index of microbial stress in the face of contamination (Wardle and Ghani, 1995).

The result in Figure 5 showed that the day 28 had the highest value of $156.44 \pm 30.24 \mathrm{\mu g} / \mathrm{g}$ on pig dung and day 1 had the lowest value of $23.28 \pm 4.13 \mu \mathrm{g} / \mathrm{g}$ on cow dung. The result also showed that protease activity increased with time till day 28 after which it decreased along all treatments. Statistically, there was no significant difference detected in all the set ups indicating that the organic and inorganic nutrients did not enhance protease activity better than the control set up during the 56 days incubation period. Proteins represent a significant reservoir of organic nitrogen in most terrestrial ecosystems and therefore comprise a key component of the soil nitrogen cycle. Microbes need protein to build their bodies and proteases are required to break these proteins in order to be assimilated into the body mass (Hegazy et al., 2014).

The germination index (Gl) gives an idea of the effect of contamination on both seed germination and root growth. The result in Figure 6 showed that the soil contaminated with diesel showed the lowest value of $0.00 \pm 0.00 \%$ in day 56 on all the set ups while the day 14 had the highest value 


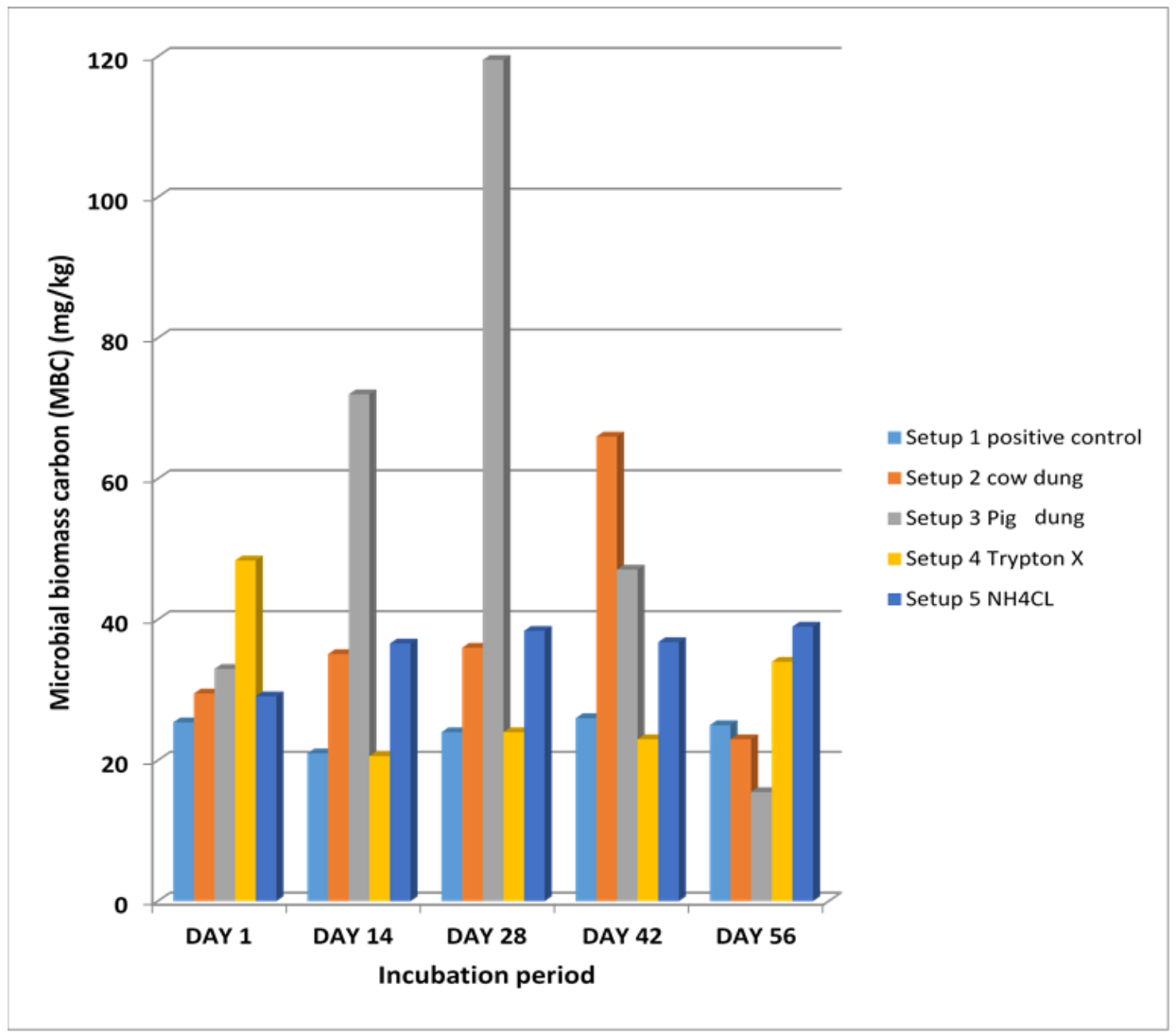

Figure 4. Dynamic changes of microbial biomass carbon (MBC) in diesel contaminated soils in the presence and absence of cow dung, pig dung, triton $\mathrm{X}$ and $\mathrm{NH}_{4} \mathrm{Cl}$ nutrients of during incubation for 56 days.

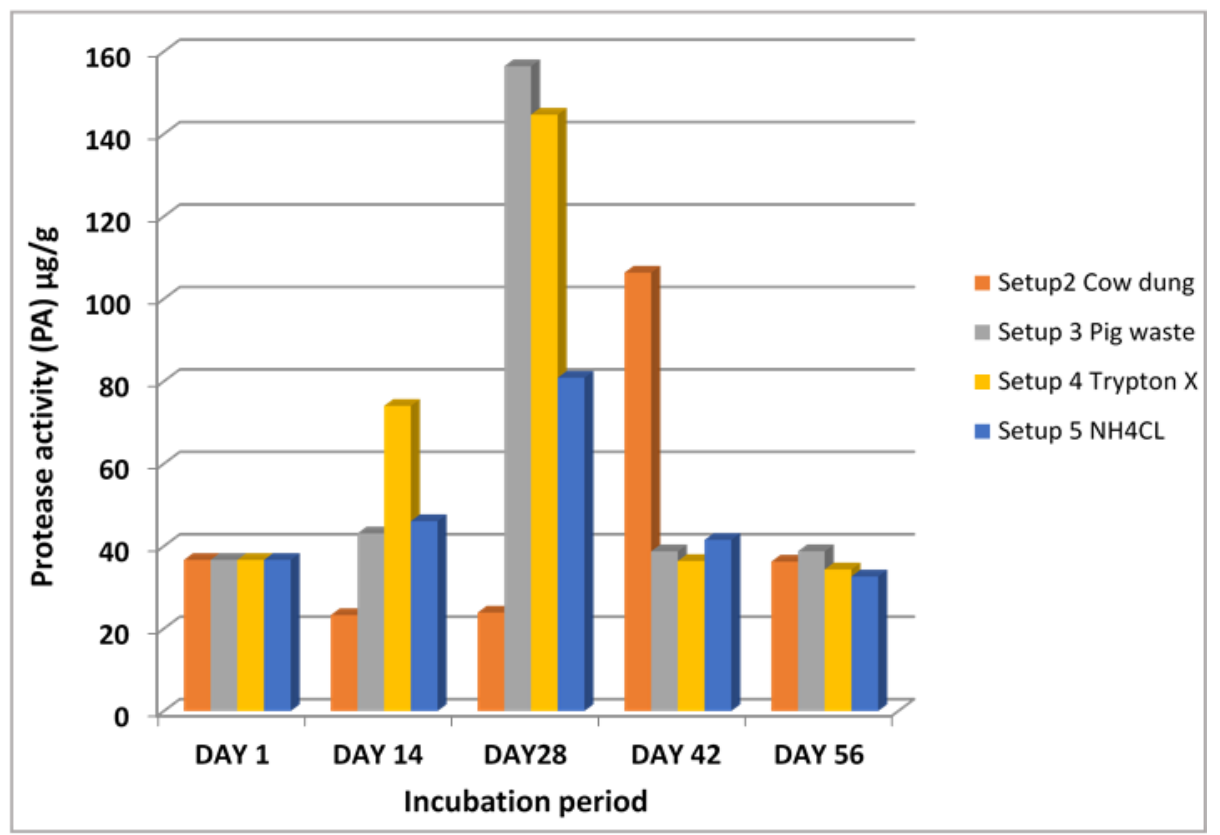

Figure 5. Dynamic changes of protease activity in diesel contaminated soils in the presence and absence of cow dung, pig dung, triton $\mathrm{X}$ and $\mathrm{NH}_{4} \mathrm{Cl}$ nutrients during incubation for 56 days. 


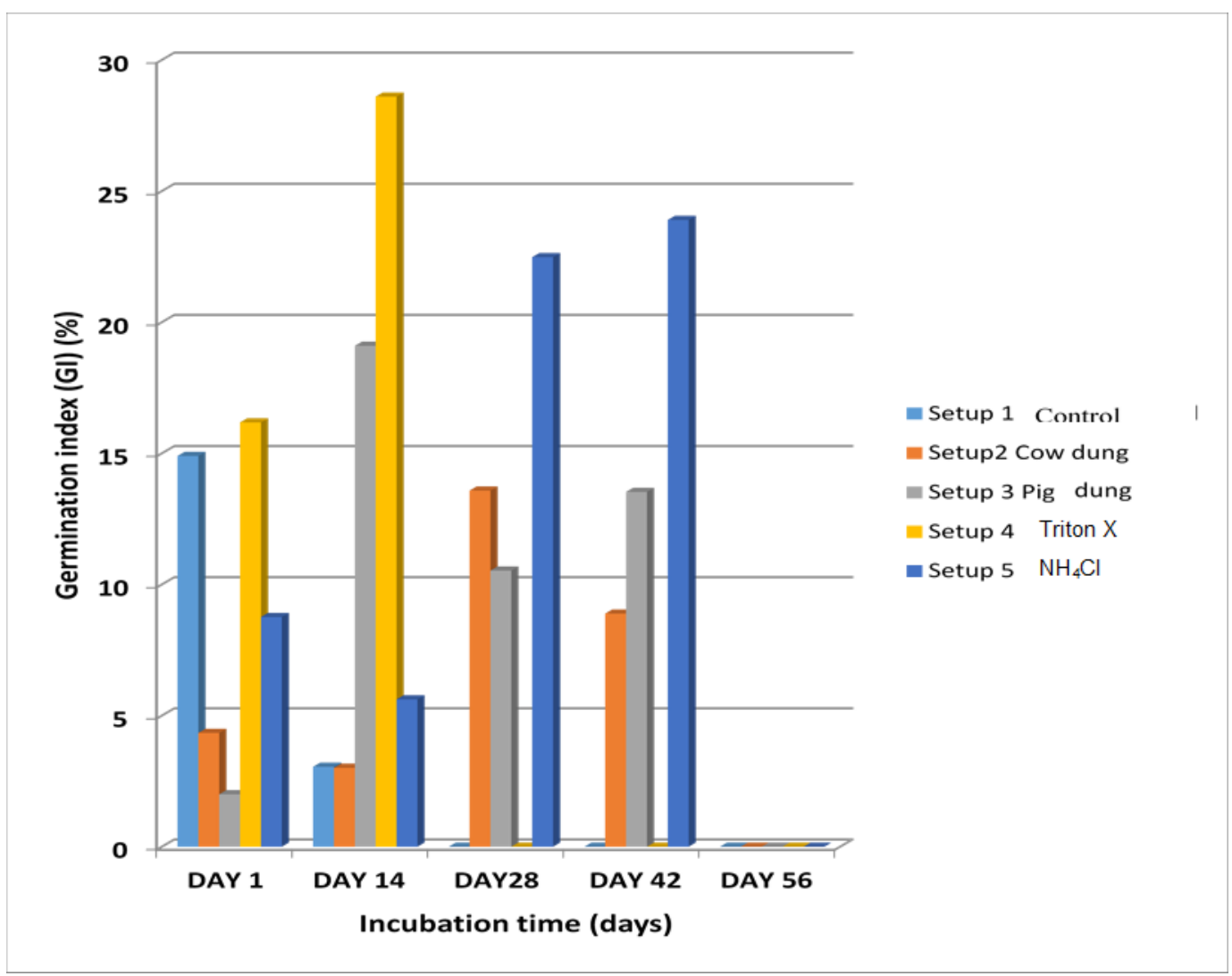

Figure 6. Germination index (GI) of mustard seeds in diesel contaminated soils in the presence and absence of cow dung, pig dung, triton $\mathrm{X}$ and $\mathrm{NH}_{4} \mathrm{Cl}$ nutrients during incubation for 56 days.

of $28.60 \pm 0.10 \%$ on triton $X$ set up. The control set up showed the lowest GI value from day 14 to day 56 with values of $3.05 \pm 0.10$ to $0.00 \pm 0.00 \%$. The inhibitory effect produced by diesel was highest in day 56 with germination index of $0.00 \pm 0.00 \%$ but the addition of the organic and inorganic nutrients had a stimulatory effect on mustard seed germination (Figure 6) making inhibitory effect to decrease. From the beginning to 56 day of the experiment, day 28 to day 56 of control and triton X GI values were completely inhibited by diesel. This may be that the diesel entered the seeds and changed the metabolic reactions of the embryo by direct and acute toxicity after penetrating the plants tissues, this damaged cell membrane and decreased the metabolic transport and respiration rate (Amadi et al., 1992; Xu and Johnson, 1995). Cow dung had a little high GI value of $13.58 \pm 0.20 \%$ in day 28 and finally decreased to $0.00 \pm 0.00 \%$ in day 56 while addition of pig dung had a higher Gl value of $19.10 \pm 0.30 \%$ in day 14 and finally decreased to $0.00 \pm 0.00 \%$ in day 56 . Increase was seen more in $\mathrm{NH}_{4} \mathrm{Cl}$ from day 1 to day 42 with GI values varying from $8.76 \pm 0.15$ to $23.90 \pm 2.30 \%$ and finally decreased to $0.00 \pm 0.00 \%$ in day 56 . There was a negative correlation between germination index, soil respiration and protease activity $(r=-0.156 ;-0.562)$ but positive correlation between germination index, dehydrogenase activity, urease activity and microbial biomass carbon ( $r=0.872 ; 0.187 ; 0.369)$. Emami et al. (2014) reported similar finding though with different substrates. They found out that the soils contaminated with petroleum showed the lowest GI values, and the inhibitory effect produced by petroleum were higher at the higher level of contamination, while addition of $\mathrm{N}$ fertilizer had a stimulatory effect on wheat seed germination. Statistically, there were no significant differences $(P>0.05)$ detected among the stimulatory effect of the organic and inorganic nutrients indicating that all the amended set ups had same effect on seed germination and growth.

\section{Microbial analysis}

The result in Figure 7 showed the increase in THBC with the control, cow dung, pig dung, triton $\mathrm{X}$ and $\mathrm{NH}_{4} \mathrm{Cl}$ THBCs ranging from $8.52 \pm 0.60$ to $8.92 \pm 0.80 \mathrm{CFU} / \mathrm{g}, 8.83 \pm$ 0.23 to $8.98 \pm 0.20 \log$ CFU / g, $8.85 \pm 0.40$ to $9.11 \pm 1.00$ $\log \mathrm{CFU} / \mathrm{g}, 8.79 \pm 0.15$ to $8.95 \pm 0.32 \log \mathrm{CFU} / \mathrm{g}$ and $8.48 \pm 0.24$ to $8.90 \pm 0.10 \log$ CFU / g respectively. The pig dung set up had the highest THBC of $9.11 \pm 0.11 \mathrm{log}$ CFU / $g$ on day 56 while control set up having the lowest THBC of $8.52 \pm 0.20 \log$ CFU / g on day 1. Similarly, the result in Figure 8 showed that the TCHUBC for cow dung, pig dung, Triton $\mathrm{X}$ and $\mathrm{NH}_{4} \mathrm{Cl}$ amended soil increased 


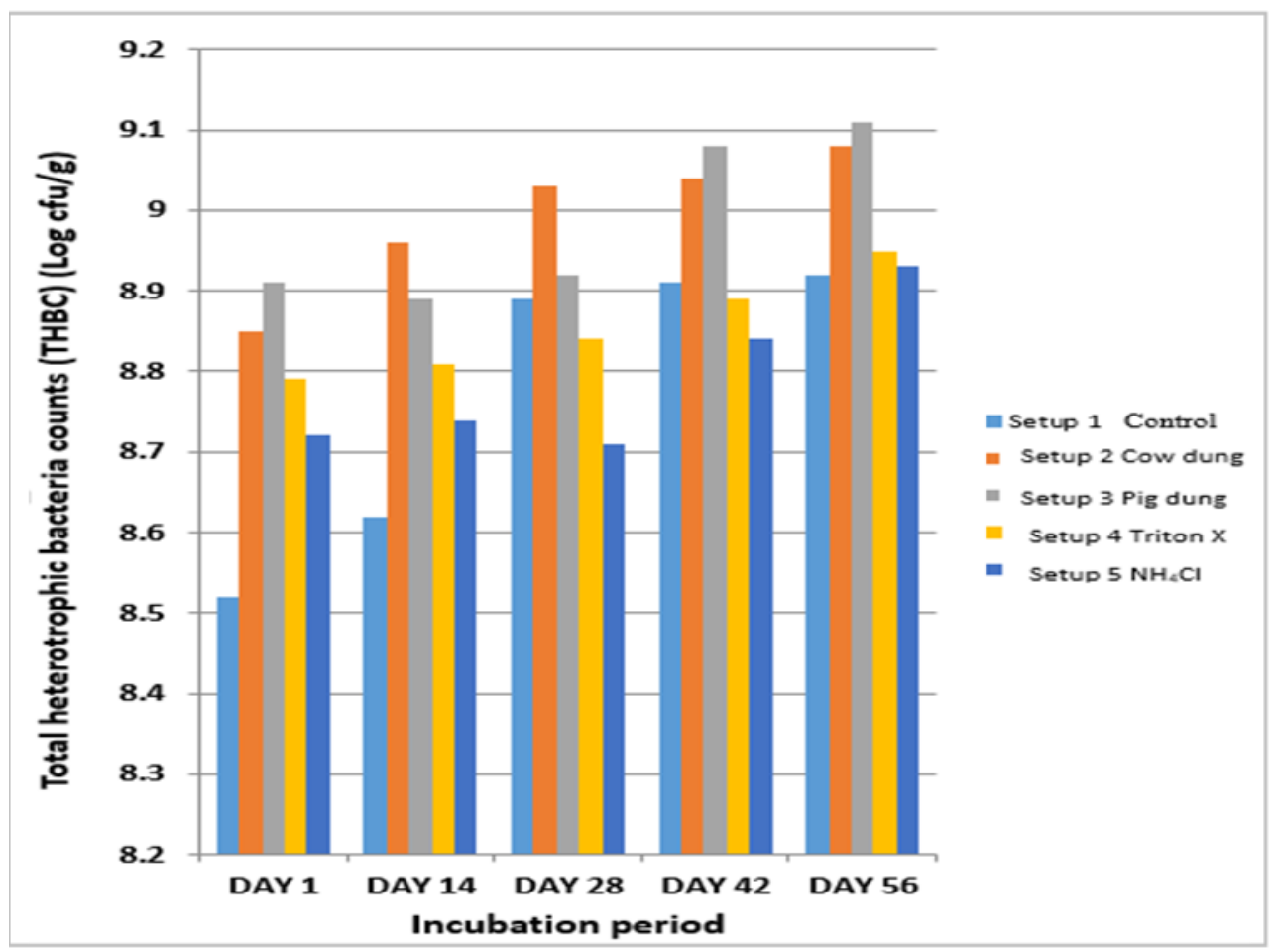

Figure 7. Changes in total heterotrophic bacteria counts (THBC) of diesel contaminated soils in the presence and absence of cow dung, pig dung, triton $\mathrm{X}$ and $\mathrm{NH}_{4} \mathrm{Cl}$ nutrients during incubation for 56 days.

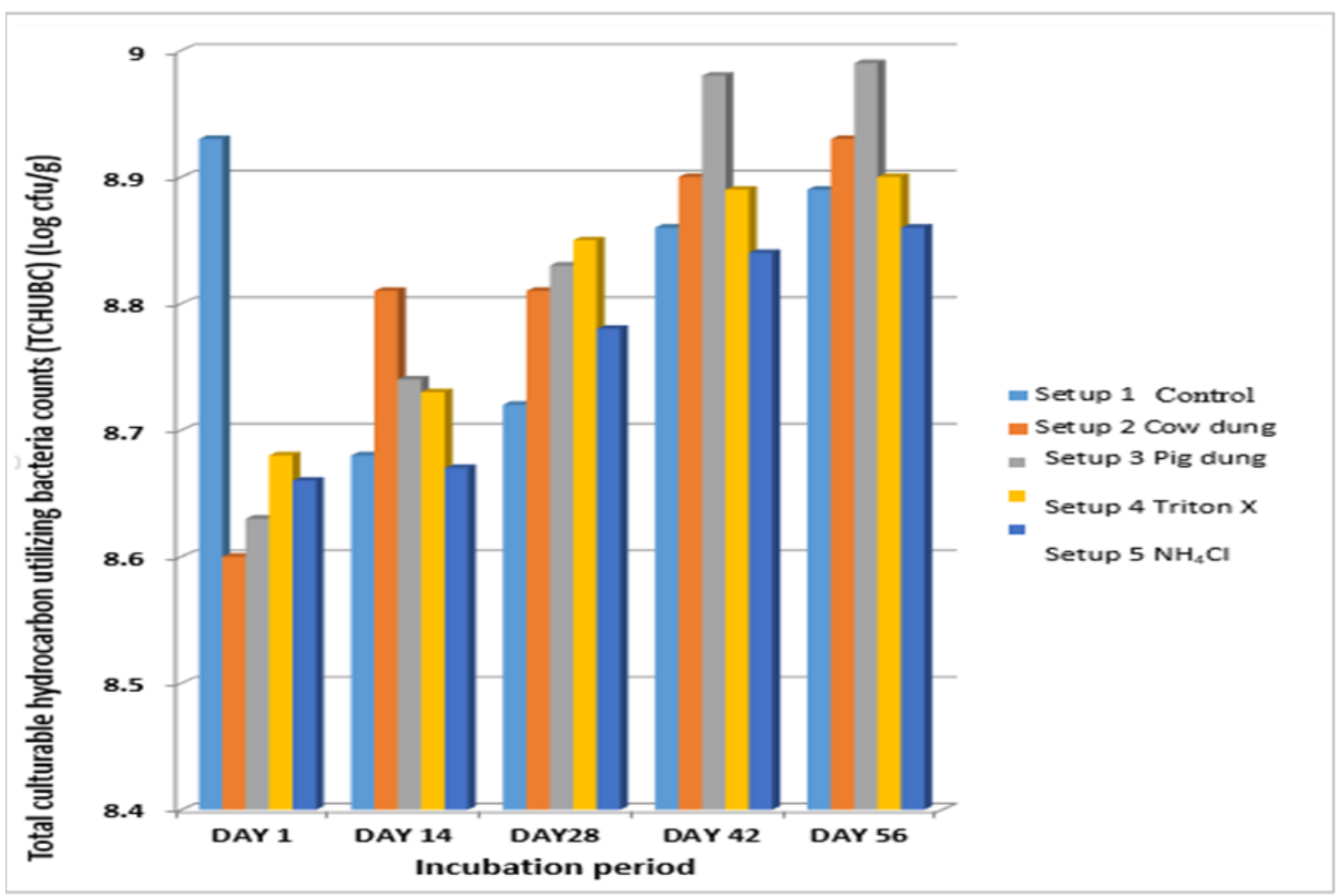

Figure 8. Changes in total culturable hydrocarbon utilizing bacteria counts (TCHUBC) of diesel contaminated soils in the presence and absence of cow dung, pig dung, triton $\mathrm{X}$ and $\mathrm{NH}_{4} \mathrm{Cl}$ nutrients during incubation for 56 days. 
Table 5. Microscopic and biochemical characterization of the hydrocarbon utilizing bacterial isolates.

\begin{tabular}{|c|c|c|c|c|c|}
\hline Test & Aeromonas sp. & $\begin{array}{c}\text { Serratia } \\
\text { fonticola }\end{array}$ & $\begin{array}{l}\text { Citrobacter } \\
\text { freundii }\end{array}$ & $\begin{array}{c}\text { Citrobacter } \\
\text { diversus }\end{array}$ & $\begin{array}{c}\text { Corynebacterium } \\
\text { sp. }\end{array}$ \\
\hline Gram reaction & - Rods & - Rods & - Rods & - Rods & + Rods \\
\hline ONPG & + & - & - & + & + \\
\hline $\mathrm{ADH}$ & + & + & - & + & - \\
\hline LDC & + & + & + & + & + \\
\hline ODC & + & + & + & + & + \\
\hline Citrate & + & + & + & + & + \\
\hline $\mathrm{H}_{2} \mathrm{~S}$ & - & - & + & + & - \\
\hline Urease & - & - & - & - & - \\
\hline TDA & + & + & + & - & + \\
\hline Indole & - & - & - & + & - \\
\hline VP & - & - & - & - & - \\
\hline Gelatinase & + & + & + & - & + \\
\hline Glucose & + & + & - & + & + \\
\hline Mannitol & + & + & + & + & + \\
\hline Inositol & - & - & - & + & - \\
\hline Sorbitol & + & + & - & - & + \\
\hline Rhamnose & + & + & - & + & + \\
\hline Saccharose & + & + & - & + & + \\
\hline Melbiose & + & + & - & + & + \\
\hline Amigdalina & + & + & - & - & + \\
\hline Arabinose & - & - & - & - & - \\
\hline Nitrite & - & - & + & + & - \\
\hline Nitrogen & + & + & + & + & + \\
\hline Oxidase & + & - & - & - & - \\
\hline Catalase & + & + & + & + & + \\
\hline
\end{tabular}

Key: + = Positive; - = Negative, ONPG = 2-nitrophenyl-B-D-galactopyranoside; ADH = Arginine dehydrolase; LDC = Lysine decarboxylase; $\mathrm{ODC}=$ Ornithine decarboxylase; $\mathrm{H}_{2} \mathrm{~S}=$ Hydrogen sulfide production; TDA = Tryptophan deaminase; VP = Voges Proskauer Test.

while control decreased from day 1 to day 56 with TCHUBCs ranging from of $8.60 \pm 0.50$ to $8.93 \pm 0.34 \mathrm{log}$ $\mathrm{CFU} / \mathrm{g}, 8.63 \pm 0.23$ to $8.99 \pm 0.12 \log \mathrm{CFU} / \mathrm{g}, 8.68 \pm 0.10$ to $8.98 \pm 0.35 \log \mathrm{CFU} / \mathrm{g}, 8.66 \pm 0.14$ to $8.860 .09 \log$ $\mathrm{CFU} / \mathrm{g}$ and $8.93 \pm 0.06$ to $8.89 \pm 0.04 \mathrm{log} \mathrm{CFU} / \mathrm{g}$ respectively. Pig dung had the highest TCHUBC of $8.99 \pm$ $0.04 \log \mathrm{CFU} / \mathrm{g}$ on day 56 while cow dung had the lowest TCHUBC of $8.60 \pm 0.08 \mathrm{CFU} / \mathrm{g}$ on day 1 . It is evident that there are more THBC than TCHUBC in the nutrient amended set ups than the control set up. The reason for the higher counts of the bacteria in amended soil may also be as a result of the presence of appreciable quantities of growth factors associated with the organic and inorganic nutrient supplements used. These elements are necessary nutrients for bacterial biodegradative activities (Romanus et al., 2015). There was a negative correlation between TCHUBC, dehydrogenase activity, urease activity, protease activity and germination index $(r=-0.334$; 0.361 ; 0.146 ; - 0.497 ) but positive correlation between TCHUBC, soil respiration, microbial biomass carbon and THBC $(r=0.268 ; 0.197 ; 0.637)$. Similar results were reported by several researchers who observed counts of hydrocarbon utilizers in oil - polluted soil to be $\times 10^{6} \mathrm{CFU} /$ g (ljah and Antai, 2003; Onuoha, 2013), but lower than those obtained by Antai and Mgbomo (1989), whose TCHUBC in hydrocarbon - contaminated soil was $\times 10^{8}$ CFU / g. However, this may be due to differences in microbial ecology of the soil or characteristics of the experimental soil.

The result in Table 5 indicated that most of the hydrocarbon degraders were Gram negative rods; positive to O-nitrophenyl- -D-galactopyranoside arginine dihydrolase, lysine decarboxylase, ornithine decarboxylase, citrate, tryptophan deaminase, gelatinase, glucose, mannitol, sorbitol, rhamnose, saccharose, melbiose, amigdalina, nitrogen but negative to urease, indole, Voges - Proskauer, inositol, arabinose, nitrite and oxidase biochemical tests. The organisms were identified to be Aeromonas sp., Serratia fonticola, Citrobacter freundii, Citrobacter diversus and Corynebacterium sp. Some of these bacteria have been reported earlier in relation to hydrocarbon biodegradation (van Hamme et al., 2003; Riffaldi et al., 2006; Akpe et al., 2015). The higher occurrence of Gram negative over Gram positive bacteria 
in this study agrees with the earlier report that both Gram positive and Gram negative bacteria were encountered in the degradation of contaminants with Gram negative bacteria dominating (Romanus et al., 2015). These findings also correlate the report of previous researchers (Foght and Westlake, 1987; Esumeh et al., 2009, Omoni et al., 2015) who isolated more of Gram negative organisms suggesting that they are better degraders of crude oil when compared with Gram positive organisms. The higher ability of Gram negative bacteria to utilize crude oil may not be unconnected with the possession of plasmid - borne or chromosomal genes involved in hydrocarbon degradation and porins in their cell wall which helps in the uptake of certain substances by the cell or extrusion of others which may be harmful (Romanus et al., 2015).

Comparatively, both the organic nutrients (cow dung and pig dung) and the inorganic (triton $\mathrm{X}$ and $\mathrm{NH}_{4} \mathrm{Cl}$ ) nutrients were effective and comparable in the bioremediation of diesel polluted soils which contradict the findings of Ezekoye et al. (2015) who reported that NPK (15:15:15), though expensive compared to poultry droppings was more effective in the bioremediation of hydrocarbon polluted soils compared with poultry droppings.

\section{Conclusion}

In conclusion, the results obtained from this study indicate that bioremediation of diesel contaminated soil with the use of organic (cow dung and pig dung) and inorganic (triton $\mathrm{X}$ and $\mathrm{NH}_{4} \mathrm{Cl}$ ) nutrients as biostimulating agents resulted in the positive and negative responses of the soil biological indicators. The results also showed that hydrocarbon degrading bacteria were present not only in the soil but also in the organic and inorganic nutrients used for amendment. The significant reduction in phytotoxicity was complimentary with increase in microbial count, soil respiration, protease activity and decrease in dehydrogenase activity, urease activity and soil microbial biomass carbon measured. The inorganic nutrients in this study favourably enhanced the activities of soil biological indicators comparable to the organic nutrients as significant differences was not detected $(P>0.05)$ in their effects to the soil biota. Thus, the application of these nutrients has widened our knowledge on biological indicators assessment for bioremediation of diesel contaminated soils.

\section{AUTHORS CONTRIBUTION}

This work was carried out in collaboration between all authors. Authors BOU and TA designed the study, performed the statistical analysis, wrote the protocol and the first draft of the manuscript. Author ELO managed the analyses of the study. Author CUD and OMN managed the literature searches. All authors read and approved the final manuscript.

\section{CONFLICT OF INTEREST}

The authors declare that there is no conflict of interest in regard to the publication

\section{REFERENCES}

Agamuthu, P., Tan, Y. S., \& Fauziah, S.H. (2013). Bioremediation of hydrocarbon contaminated soil using selected organic wastes. In: 2013 International Symposium on Environmental Science and Technology (2013 ISEST). Procedia Environmental Sciences, 18, 694-702.

Agarry, S. E. (2018). Evaluation of the effects of inorganic and organic fertilizers and activated carbon on bioremediation of soil contaminated with weathered crude oil. Journal of Applied Science and Environment Management, 22(4), 587-595.

Akhtar, N., Mahmud, A. S. M., Khan, M. S., Taznin, T., Haque, M. E., Sultana, S., \& Anwar, M. N. (2013). Effects of cultural conditions on the production of extracellular protease by Streptomyces albolongus and Streptomyces aburaviensis. ARPN Journal of Science and Technology, 3(8), 892 -899

Akpe, A. R., Esumeh, F. I., Aigere, S. P., Umanu, G. and Obiazi, $H$. (2015). Efficiency of plantain peels and guinea corn shaft for bioremediation of crude oil polluted soil. Journal of Microbiology Research, 5 (1), 31-40.

Akubugwo, E. I., Ogbuji, G. C., Chinyere, C. G., \& Ugbogu, E. A. (2009). Physicochemical properties and enzymes activity studies in a refined oil contaminated soil in Isiukwuato, Abia State, Nigeria. Nigerian Society for Experimental Biology, 21(2), 79-84.

Amadi, A., Dickson, A. A., \& Maate, G. O. (1992). Remediation of oil polluted soils: effect of the organic and inorganic nutrient supplements on the performance on maize (Zea mays L.). Water Air Soil Pollution, 66, 59-76.

Antai, S. P., \& Mgbomo, E. (1989). Distribution of hydrocarbon utilizing bacteria in oil - spill areas. Microbiology Letters, 40, 137-143.

Association of Official Analytical Chemists (AOAC) (2012). Official method of analysis. 19 ${ }^{\text {th }}$ edn. Association of Official Analytical Chemists, Washington DC. Pp.121-130.

Cheesbrough, M. (2006). District laboratory practice in tropical countries. Part 2, $2^{\text {nd }}$ edn. Cambridge University Press, New York USA. Pp. 38-70.

Chikere, C. B., Okpokwasili, G. C., \& Chikere, B. O. (2009a). Bacterial diversity in a tropical crude oil-polluted soil undergoing bioremediation. African Journal of Biotechnology, 8(11), 2535-2540.

Chikere, C. B., Okpokwasili, G. C., \& Ichiakor, O. (2009b). Characterization of hydrocarbon utilizing bacteria in tropical marine sediments. African Journal Biotechnology, 8(11), 25412544.

Corstanje, R., Schulin, R., \& Lark, R. (2007). Scale dependent relationships between soil organic matter and urease activity. European Journal of Soil Science, 58(5), 1087-1095.

Ebuehi, O. A. T., Abibo, I. B., Shekwolo, P. D., Sigismund, K. I., Adoki, A., \& Okoro, I. C. (2005). Remediation of crude oil contaminated soil by enhanced natural attenuation technique. Journal of Applied Environmental Management, 9(1), 103-106.

Emami, S., Pourbabaei, A. A., \& Alikhani, H. A. (2014). Interactive effect of nitrogen fertilizer and hydrocarbon pollution on soil biological indicators. Springer Environmental Earth Science, 72(9), 3513-3519.

Esumeh, F. I., Akpe, A. R., \& Eguagie, O. E. (2009). Crude oil 
degrading capabilities of bacterial isolates from pawpaw (Carica papaya) and sweet orange (Citrus sinensis). A role for plasmid mediated gene. Proceedings of the 1st international conference, workshop and exhibition on biotechnologies for improved production of oil and gas in the Gulf of Guinea, held in Abuja, Nigeria 1. April 1-3. 2009. BIPOG3-4-34. Pp. 1-7.

Ezekoye, C. C., Amakoromo, E. R., \& Ibiene, A. A. (2015). Bioremediation of hydrocarbon polluted mangrove swamp soil from the Niger Delta using organic and inorganic nutrients. British Journal of Biotechnology, 6(2), 62- 78.

Eziuzor, C. S., \& Okpokwasili, G. C. (2009). Bioremediation of hydrocarbon contaminated mangrove soil in a bioreactor. Nigerian Journal of Microbiology, 23(1), 1777-1791.

Foght, J. M., \& Westlake, D. W. S. (1987). Biodegradation of hydrocarbon in fresh waters, In: Vandermuelen, J. H., \& Hrudy, S. E. (Eds.). Oil in freshwater: Chemistry, biology, counter measure technology. Pergamon Press, New York USA. Pp. 252-263.

Gianfreda, L., Sannino, F., Ortega, N., \& Nannipieri, P. (1994). Activity of free and immobilized urease in soil: effects of pesticides. Soil Biology and Biochemistry, 26(6), 777-784.

Griffiths, B. S., Faber, J., \& Bloem, J. (2018). Applying soil health indicators to encourage sustainable soil use: The transition from scientific study to practical application. Sustainability, 10(9),3021. 14p.

Hegazy, T. A., Ibrahim, M. S., El- Hamid, H. T. A., \& El-Moselhy, K. M. (2014). Microcosm application for Improving Biodegradation potentials of diesel oil contaminated marine sediments. International Journal of Advanced Research, 2(9), 623-631.

Holt, J. G., Kreig, N. R., Sneath, P. H. A., Staley, J. T., \& Williams, S. T. (1994). Bergey's manual of determinative bacteriology. 9th edn. Williams and Wilkins: A waverly Company, Baltimore Maryland, USA. Pp. 73-589.

ljah, U. J. J., \& Antai, S. P. (2003). The potential use of chicken drop microorganisms for oil spill remediation. Environmentalist, 23(1), 89-95.

Klose, S. and Tabatabai, M.A. (1999). Urease activity of microbial biomass in soils. Soil Biology and Biochemistry, 31(2), 205211.

Labud, V., Garcia, C., \& Hernandez, T. (2007): Effect of hydrocarbon pollution on the microbial properties of a sandy and a clay soil. Chemosphere, 66(10), 1863-1871.

Leahy, J. G., \& Colwell, R. R. (1990). Microbial degradation of hydrocarbons in the environment. Microbiology Revolution, 54(3), 305-315.

Makoi, J., \& Ndakidemi, P. (2008). Selected soil enzymes: examples of their potential roles in the ecosystem. African Journal of Biotechnology, 7(3), 181-191.

Malachowska, J. A., Mirozoska, J., Rozielska, M., \& Miksch, K. (1997). Enzymatic activity in soil contaminated by petroleum derivatives during the process of its detoxication. Journal of Biotechnology, 36, 79-91.

Margesin, R., Zimmerbauer, A., \& Schinner, F. (2000). Monitoring of bioremediation by soil biological activities. Chemosphere, 40(4), 339-346.

Marın, J. A. (2004). Bioremediation by mean of biological techniques of hydrocarbons from oil refinery sludges experiments under semiarid climate. Ph.D Thesis, University of Murcia.

Marschner, B., \& Kalbitz, K. (2003). Controls of bioavailability and biodegradability of dissolved organic matter in soils. Geoderma, 113(3-4), 211-235.

Mckee, K. L., Mendelssohn, I. A., \& Hester, M. W. (1988).
Reexamination of pore water sulfhde concentrations and redox potentials near the aerial roots of Rhizophora mangle and Avicennia germinans. American Journal of Botany, 75(9), 1352-1359.

Nannipieri, P., Sequi, P., \& Fusi, P. (1996). Humus and enzyme activity. In: Piccolo, A. (Ed.) Humic substances in terrestrial ecosystems. Elsevier, Amsterdam, Netherlands. Pp. 293-327.

Nelson, D. W., \& Sommers, L. E. (1975). A rapid and accurate method for estimating organic carbon in soil. Proceedings of seminar on the petroleum industry and the Nigerian environment. NNPC/FMW and H, Warri, Nigeria. Pp. 164-170.

Obire, O., Anyanwu, E. E., \& Okigbo, R. N. (2008). Saprophytic and crude oil degrading fungi from cow dung and poultry droppings as bioremediating agents. Journal of Agricultural Technology, 4(92), 81-89.

Omoni, V. T., Aguoru, C. U., Edoh, E. O., \& Makinde, O. (2015). Biostimulation of hydrocarbon utilizing bacteria in soil contaminated with spent engine oil using banana and plantain agro-wastes. Journal of Soil Science and Environmental Management, 6(8), 225-233.

Onuoha, S. C. (2013). Stimulated biodegradation of spent lubricating motor oil in soil amended with animal droppings. Journal of National Sciences and Resources, 3(12), 106-116.

Orji, F. A., Abiye, A. I., \& Dike, E. N. (2012a). Laboratory scale bioremediation of petroleum hydrocarbon - polluted mangrove swamps in the Niger Delta using cow dung. Malaysian Journal of Microbiology, 8(4), 219-228.

Orji, F. A., Ibiene, A. A., Uzomba, P. C., Itoandon, E. E., \& Nwachukwu, N. C. (2012b). Cow dung and water hyacinth nutrient powder: good sources of limiting nutrients for bioremediation of hydrocarbon polluted mangrove swamps in the Niger Delta, Nigeria. Nigerian Journal of Agriculture, Food and Environment, 8(2), 52-58.

Pepper, I. L., Gerba, C. P., \& Brendecke, J. W. (1995). Environmental microbiology: a laboratory manual. Academic Press Inc. New York, USA.

Rajaei, S., Seyedi, S. M., Raiesi, F., Shiran, B., \& Raheb, J. (2013). Characterization and potentials of oil-degrading bacteria inhabiting the rhizosphere of wild oat (Avena Fatua L.) in South West of Iran. Iranian Journal of Biotechnology, 11(1), 32-40.

Riffaldi, R., Levi-Minzi, R., Cardelli, R., Palumbo, S., \& Saviozzi, A. (2006). Soil biological activities in monitoring the bioremediation of diesel oil-contaminated soil. Water, Air and Soil Pollution, 170, 3-15.

Romanus, A. A., Omolola, E. A., Patrick, A. S., \& Ifeoma, O.G. (2015). Bacterial degradation of petroleum hydrocarbons in crude oil polluted soil amended with cassava peels. American Journal of Research Communication, 3(7), 99-118.

Salleh, A. B., Ghazali, F. M., Zaliha, R. N., Rahman, A., \& Basri, M. (2003). Bioremediation of petroleum hydrocarbon pollution. Indian Journal of Biotechnology, 2, 411-425.

Singh, D. K., \& Kumar, S. (2008). Nitrate reductase, arginine deaminase, urease and dehydrogenase activities in natural soil (ridges with forest) and in cotton soil after acetamiprid treatments. Chemosphere, 71, 412-418.

Topac, F. O., Dindar, E., Ucaroglu, S., \& Baskaya, H. S. (2009). Effect of a sulfonated azo dye and sulfanilic acid on nitrogen transformation processes in soil. Journal of Hazardous Materials, 170(2-3), 1006-1013.

Ueno, A., Ito, Y., Yumoto, I., \& Okuyama, H. (2007). Isolation and characterization of bacteria from soil contaminated with diesel oil and the possible use of these in autochthonous bioaugmentation. World Journal of Microbiology and 
Biotechnology, 23(12), 1739-1745.

United Nations Environmental Programme (2004). Analytical methods for water quality. Burllinton Publishing House, Ontario, Canada. p. 160.

van Hamme, J. D., Singh, A., \& Ward, O. N. W. (2003). Recent advances in petroleum microbiology. Microbiological and Molecular Biology Review, 67(4), 503-549.

Vance, E. D., Brookes, P. C., \& Jenkinson, D. S. (1987). An extraction method for measuring soil microbial biomass $C$. Soil Biology and Biochemistry, 19(6), 703-707.
Wardle, D. A., \& Ghani, A. (1995). A critique of the microbial metabolic quotient (qCO2) as a bioindicator of disturbance and ecosystem development. Soil Biology and Biochemistry, 27(12), 1601-1610.

Xu, J. G., \& Johnson, R. L. (1995). Root growth, microbial activity and phosphatase activity in oil - contaminated, remediated and uncontaminated soils planted to barley and field pea. Plant Soil, 173(1), 3-10. 